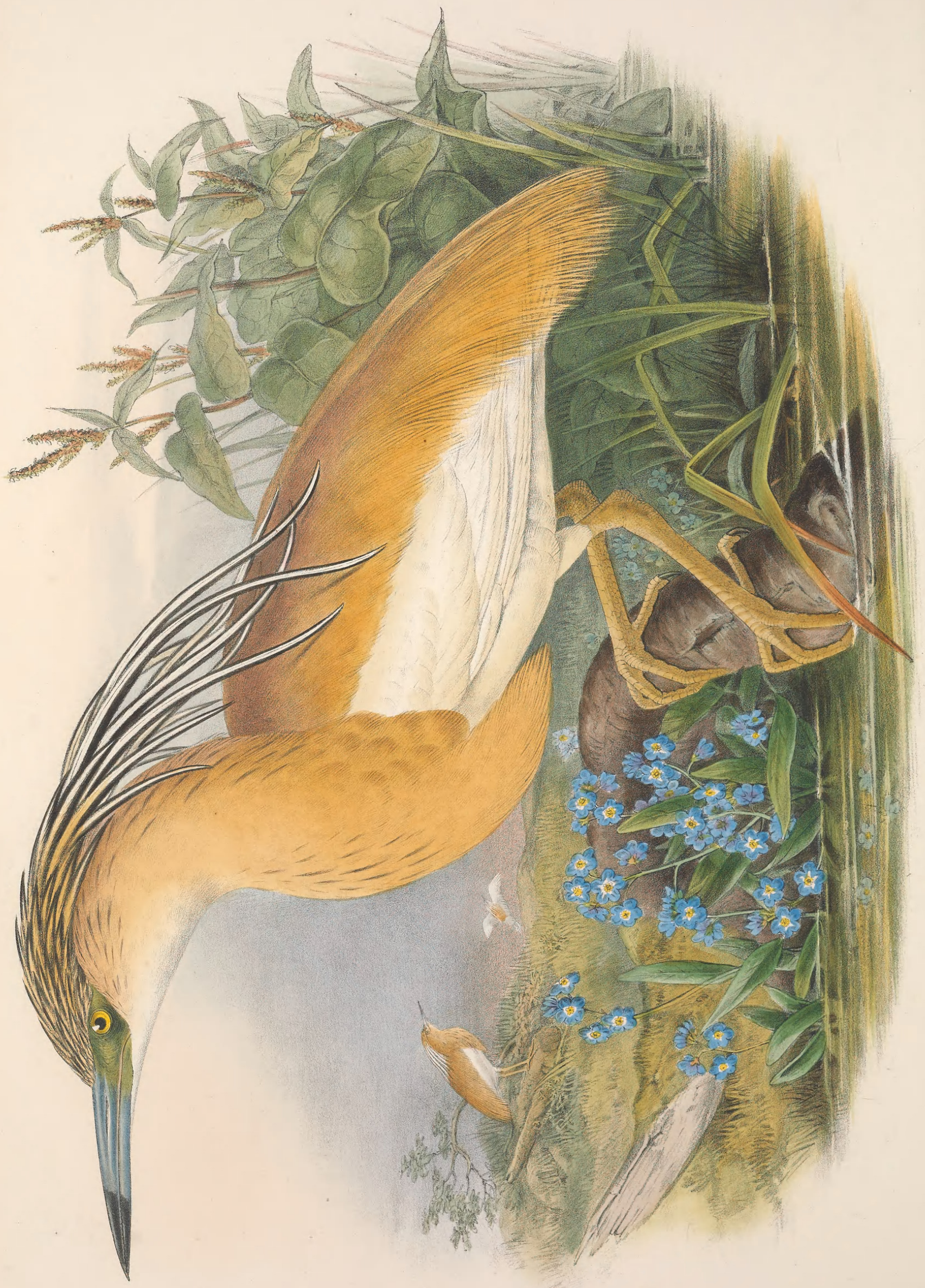




\section{BUPHUS COMATUS.}

\section{Squacco Heron.}

Ardea comata, Pall. Reise, tom. ii. p. 715 .

- ralloides, Scop. Ann. Hist. Nat., tom. i. no. 121.

- squaiotta, castanea, et erythropus, Gmel. edit. Linn. Syst. Nat., tom. i. pp. 633, 634.

audax, La Peyr. Neue Schwed. Abh., tom. iii. p. 306.

- Marsigli, Lepechin, Nov. Comm. Petrop., tom. xiv. p. 502, tab. 14, fig. 1.

pumila, Lepechin, ibid., p. 502.

Ardeola ralloides, Boie, Isis, 1822, p. 559.

Buphus comatus, Boie, Isis, 1826, p. 356.

castaneus et ralloides, Brehm, Vög. Deutschl. p. 589

Illyricus, Brehm, ib , p. 590, tab. 31. fig. 1.

Egretta comata, Swains. Class. of Birds, vol. ii. p. 354

Botaurus comatus, Macgill. Man. of Nat. Hist., Orn., vol. ii. p. 125.

Cancrophagus ralloides (Boie), Kaup, Natürl. Syst., p. 42.

ON the banks of Old Father Thames, within twenty-five miles of London, the pleasure-seeker may gratify his taste by land or by water, and the lover of nature may revel in the varied character of the scenery. Such woods, waters, and meads as those of Taplow, Cliveden, and Hedsor, my own favourite resorts for observation, form such an elysium for the naturalist as rarely occurs. I was once standing at the door of the celebrated inn of this charming locality, when a person in the garb of a gentleman hurried out and eagerly inquired for the next train to London, adding that one hour at Temple Bar was worth twelve months' life in the country. For myself I would not care if I never saw the old Temple Gate again, and would at any time leave the hurried Babel of London to hear the song of the Thrush or witness the skipping of the Bleak before the huge Trout of our queen of rivers; but he and I, with hundreds of others, each having his especial liking, are essential to make up a world. Among birds this diversity is shown in another manner; for their nature, and not their tastes, prompts each kind to affect the especial locality for which it was designed-some the mountain-tops, others the forest, the marsh, and the sea-shore. They are equally diversified in their colours and adornments, - those of the tropics being dressed in modest as well as brilliant hues, those of the snow-clad mountain in spotless as well as glittering tints, those of the stagnant waters being adorned with hues as beautiful as any of the others, while those of the seas are not wanting in variety of colouring.

It is in the swamp, in the stagnant marsh, in the still waters, where the newt wriggles in the warm shallows, and the frog croaks in the rush-beds, where the buckbean flourishes, the flowering rush raises its stately head, and the forget-me-not carpets the margin, that the beautiful bird figured in the accompanying Plate loves to dwell; for there it finds both security and an abundant supply of food. It is in such situations, in Southern Europe, that it is by no means uncommon; and it has several times been killed in the British islands ; to us, however, it is only a casual visitor, and it must therefore be regarded as one of the rarities of our avifauna.

Although most of the English counties, from Cornwall to the border, have from time to time been favoured with its presence, there is none in which it has been more frequently seen than in those of Norfolk and Suffolk. Speaking of Cornish localities in which it has occurred, Mr. Rodd enumerates St. Hilary, St. Levan, Sennen, Trereife, Madron, and Scilly, and adds that the examples obtained were generally in immature plumage, but some of them had the occipital and dorsal plumes partly developed. Mr. R. C. Musgrave informs me that a specimen in his father's, Sir George Musgrave's, possession was shot by one of his gamekeepers in June 1845 while perched on a tree at Lazonby, in Cumberland.

Mr. Stevenson, to whom I am indebted for so many notes on the birds of Norfolk, writes me word that the first recorded instance of its occurrence in that county is in Messrs. Paget's 'Sketch of the Natural History of Yarmouth,' in which it is stated that "one was caught in a bow-net hanging out to dry, by Ormesby Broad in July 1820.” In May 1831 another was shot at Oulton, near Lowestoft, in Suffolk, and is now in the collection of Mr. J. H. Gurney, at Catton. A third, killed at Ormesby or Filby, two adjoining Broads, on the 12 th of June 1834, is described in Dr. Hooker's MS. as a "singularly beautiful specimen," and was purchased by Captain Chawner of Alton, Hants, who was at that time collecting at Yarmouth. This bird is likewise referred to in some MS. notes of the late Mr. Lombe, whose splendid collection of British Birds is still in the possession of his daughter, Mrs. E. P. Clarke of Wymondham. In these notes, which were made in Mr. Lombe's copy of "Bewick," I also find a record of a fourth example, 
killed at Burlingham, in Norfolk; but no date is given, nor is this bird mentioned by any local author. Singularly enough, since 1834, this Heron does not appear to have been noticed, either in Norfolk or Suffolk, until the 26th of June 1863, when a magnificent adult male, now in my possession, was shot on Surlingham Broad, near Norwich. The marshman who shot it informed me afterwards that it appeared extremely tame, flying round and alighting on the marshy borders of the stream, and, though 'mobbed' by the rooks, was by no means alarmed at the approach of either man or boat."

Mr. John Rocke, of Clungunford House, Aston-on-Clure, informs me that a very fine specimen was killed, he believes, in 1842, under the Brown Clee Hill at Brockleton in Shropshire, by the late Mr. John Patrick, and passed into the possession of the late G. H. Dausey, Esq., of Ludlow.

According to Dr. Leith Adams, it is generally distributed over the lakes and geels of the Punjab.

Dr. Henry Giglioli mentions, in his notes on the birds observed by him at Pisa and in its neighbourhood in 1864, that " the beautiful Squacco Heron abounds in May, and I have seen flocks of it on the fenny flats between this place and Leghorn ; it prefers the places where cattle are grazing." ('Ibis,' 1865.)

Bailly, in his 'Oruithologie de la Savoie,' states that the Squacco Heron "annually visits the central regions of France, and occasionally occurs in the north and in Belgium. Individuals of all ages regularly appear in Switzerland and Savoy, the young birds at the end of the summer or during the first days of autumn, and the adults in spring, about April or May. Like the purple Heron and the small Egret, it evinces but little shyness, and, being scarcely disturbed at the sight of man, is easily approached; when alarmed by his proximity, it merely removes to a short distance and again settles on the ground, a tree, or a stump. If surprised in a thicket, it endeavours to elude observation by crouching down, drawing in its neck, and remaining still ; but if it perceives itself detected, flies away and hides at a greater distance."

The following are the other principal localities in which this interesting bird has been observed:-in the marsh of Zana in the Eastern Atlas, by Mr. Salvin; in the moist meadows round Jaffa in Southern Palestine, the Rev. H. B. Tristram; in large flocks in September in the marshes on the Red Sea, near Bas Belul, and Asab Bay, between $13^{\circ}$ and $14^{\circ}$ north latitude, by Dr. Heuglin; and Dr. Kirk, in his notes on the Zambesi region, states that it is there commonly seen in pairs, feeding in marshes and shallow water.

Mr. J. H. Gurney states that it inhabits but is not common in the colony of Natal, that it there frequents the lagoons on the coast and occasionally strays inland; and remarks that it appears to feed on insects, that its flight is heary, and that against a strong wind it is able to make but little headway.

It must not be supposed that the Squacco Heron is always adorned with the gay and beantiful dress in which I have figured it, or that the young birds during the first two years of their existence are similarly clothed; for such is not the case; the lengthened plumes which spring from the head in my figure are, I believe, seasonal, being merely assumed just prior to, and worn during, the breeding-season, after which they are thrown off. The young birds are much darker, and have the back- and neck-feathers short and mottled; but the sexes when mature are very similar, like the Bittern, to which this bird is nearly allied.

The nest of the Squacco Heron is a slight structure, very like that of the Bittern, and is placed in similar situations among the reeds. The eggs are four or five in number, of a clear bluish green, without markings of any kind.

As its trivial French name of "Héron Crabier" implies, it is stated to be a great devourer of crabs ; it also feeds upon most of the inhabitants of the marshes, from an insect to a frog, to which fish and doubtless young birds and small feeble quadrupeds are added.

It is said to be fond of associating with cattle and other animals, to sometimes perch on trees like the Mangrove Bitterns of Australia, and to be easily tamed if brought up from the nest.

The following is a description of the plumage during the pairing-season :-

The centre of the lengthened feathers of the head is yellow; and the prolonged occipital plumes are yellow at the base, gradually passing into white on their apical half, and have a broad border of deep black on each side throughout their entire length; chin and centre of the upper part of the throat white; sides of the neck, lower part of the throat, and the pendent feathers of the breast rich ochre-yellow, with a brown streak down those on each side of the posterior part of the neck and a few of those of the centre of the breast; all the upper surface of the body rich ochre-yellow, with a vinous wash on the centre of the back; wings, tail, and under surface white; irides yellow; eye-orbits and base of both mandibles green; middle portion of the bill light leaden blue, the tip black; legs and feet pale ochre-yellow; claws black.

The figure is of the natural size. The plant in the foreground is the Forget-me-not (Myosotis palustris). 


\section{$2 \mathrm{BHL}$ Biodiversity Heritage Library}

Gould, John. 1873. "Squacco Heron, Buphus comatus [PI. 25]." The birds of Great Britain 4, -. https://doi.org/10.5962/p.323984.

View This Item Online: https://www.biodiversitylibrary.org/item/221609

DOI: https://doi.org/10.5962/p.323984

Permalink: https://www.biodiversitylibrary.org/partpdf/323984

\section{Holding Institution}

Smithsonian Libraries

\section{Sponsored by}

Biodiversity Heritage Library

\section{Copyright \& Reuse}

Copyright Status: Public domain. The BHL considers that this work is no longer under copyright protection.

This document was created from content at the Biodiversity Heritage Library, the world's largest open access digital library for biodiversity literature and archives. Visit BHL at https://www.biodiversitylibrary.org. 